\title{
The Effect of Explicit Metacognitive Strategy Instruction on Reading Comprehension and Self-Efficacy Beliefs: The Case of Iranian University EFL Students
}

\author{
Hossein TAVAKOLI \\ Islamic Azad University, Izeh Branch, Iran \\ Mansour Koosha \\ Islamic Azad University, Khorasgan Branch, Iran
}

Received: 14 January 2015 / Accepted: 26 April 2015

ISSN: $1697-7467$

\begin{abstract}
This article reports on an empirical study that investigated the influence of explicit metacognitive strategy instruction on reading comprehension and self-efficacy in English as a foreign language (EFL) among university students in Iran. A randomized pretest posttest control group design was employed. The quantitative data were collected by the Survey of Reading Strategies, Motivated Strategies for Learning Questionnaire, and a reading comprehension test. The results of ANCOVA revealed that students in the experimental group showed greater achievement both in reading comprehension and self-efficacy than students in the control group.
\end{abstract}

Keywords: Explicit metacognitive strategy instruction, Reading comprehension, Self-efficacy beliefs

El efecto de la instrucción explícita de la estrategia metacognitiva en la comprensión lectora y las creencias de autoeficacia: el caso de estudiantes iraníes EFL

RESUMEN: Este artículo trata de un estudio empírico en el que se investigó la influencia de la instrucción explícita de la estrategia metacognitiva en la comprensión lectora y la autoeficacia del inglés como lengua extranjera (EFL) entre los estudiantes universitarios en Irán. Se empleó un diseño de grupo de pre-test y posttest con controles aleatorios. Los datos cuantitativos fueron recogidos en el estudio de estrategias de lectura, motivando estrategias de aprendizaje en un cuestionario y una prueba de comprensión de lectura. Los resultados del ANCOVA revelaron que los estudiantes del grupo experimental mostraban mayores logros tanto en comprensión lectora y en autoeficacia que los estudiantes del grupo control.

Palabras clave: Instrucción explícita, estrategia metacognitiva, comprensión lectora, creencias de autoeficacia

\section{INTRODUCTION}

Although successful reading comprehension requires students to tap upon a variety of skills, it has been suggested that the processes of comprehension occur at the metacognitive level where there are reading strategies such as planning before reading, monitoring of 
understanding during reading, and evaluating the reading experience (Carrell, Gajdusek, \& Wise, 1998; Paris \& Myers, 1981). Moreover, second/foreign language reading achievement has been tied with many emotional factors such as self-efficacy. Self-efficacy beliefs are context-specific, or linked to particular domains such as reading. Bandura (1993) stated that when self-efficacy is low, students tend to underachieve, despite knowing what it is they need to do to be successful. They may have the knowledge, skills, and strategies needed to succeed, but are not able to use them successfully.

In Iran, English is a foreign language and reading English is important for academic performance and success. Iranian university EFL students are required to learn reading in the classroom in order to successfully gain access to new information for academic purposes. They are also required to take some kinds of standardized tests such as TOEFL and IELTS to pursue further their studies at graduate levels. With strengthened reading abilities, they will make greater progress and attain greater development in all the academic areas (Anderson, 2002). Therefore, academic reading comprehension has become a major challenge. Many Iranian EFL students assume that the intended author's meaning lies within the printed words, leaving the reading process no more than obtaining meaning from the words on the page. They approach reading passively, relying heavily on the use of a bilingual dictionary, thereby spending countless hours laboring over direct sentence-by-sentence translations. Despite all the efforts made, their reading comprehension remains poor.

The present study, then, set out to shed light on the effectiveness of explicit metacognitive instruction on both reading achievement and self-efficacy within the framework of Iranian universities. The findings of this study might have implications for learners, teachers, and materials developers in the field of English language teaching and learning.

\section{REVIEW OF RELATED Literature}

\subsection{Metacognition}

The term metacognition literally means cognition about cognition, or more informally, thinking about thinking. The concept of metacognition is most often associated with John Flavell (1979). He defined metacognition as knowledge about cognition and control of cognition. For example, "I am engaging in metacognition if I notice that I am having more trouble learning A than B; [or] if it strikes me that I should double check $\mathrm{C}$ before accepting it as fact" (Flavell, 1976: 232). Metacognitive awareness is also used to refer to almost the same thing as metacognition. Over the years, metacognition has become an important concept in theories of cognitive psychology and educational psychology (Baker \& Brown, 1984; Flavell, 1987, 1992; Jacobs \& Paris, 1987; Hacker, 1998). Recently, the notion has been applied to the study of second/foreign language learners in the field of TESOL and applied linguistics in general (e.g., Wenden, 1987; Zhang, 2001, 2010).

\subsection{Metacognitive strategies}

According to Alexander and Jetton (2000), metacognitive processing is expressed through metacognitive strategies which are procedural, purposeful, effortful, willful, essential and 
facilitative in nature. Metacognitive strategies are regarded as high order executive skills that make use of knowledge of cognitive processes and involve thinking about the learning process, planning for learning, monitoring the learning task, and evaluating how well one has learned (Chamot \& Kupper, 1989; Wenden, 1998).

\subsection{Self-efficacy}

The concept of self-efficacy which is rooted in the socio-cognitive theory was proposed for the first time by Bandura (1986). According to Bandura, "Self-efficacy is people's judgments of their capabilities to organize and execute courses of action required to attain designated types of performances" (p. 391). Basically, it concerns the answer to the question, "Can I do this task in this situation?" Bandura (1997) notes, "People's level of motivation, affective state, and action are based more on what they believe than on what is objectively true" (p. 24). For this reason, how people behave can often be better predicted by the beliefs they hold about their capabilities than by what they are actually capable of accomplishing.

A number of studies have indicated that self-efficacy has a significant and positive correlation with learner's academic performance and achievement (e.g., Chou, 2007; Coutinho \& Neuman, 2008; Mills, Pajares, \& Herron, 2007; Wu, 2006; Barkley, 2006; Gahungu, 2007; Nevil, 2008; Chemens, Hu, \& Garcia, 2001). According to Margolis \& McCabe (2006), students with a strong self-efficacy are more likely to challenge themselves with difficult tasks and be intrinsically motivated. Self-efficacious students will exert a high amount of effort in order to meet their commitments, and attribute failure to factors which are in their control, rather than to external factors. These students recover quickly from setbacks, and ultimately are likely to achieve their personal objectives. Yet, students with low self-efficacy believe they cannot be successful and thus are less likely to make a concerted, extended effort and may consider challenging tasks as threats that are to be avoided.

\subsection{Metacognitive strategies and self-efficacy}

Self-efficacy is found to be significantly associated with metacognitive strategies. For example, Kanfer and Ackerman (1989) showed that students who have high self-efficacy were more likely to use metacognitive strategies when working on a task than those with low self-efficacy. Similarly, Bouffard-Bouchard, Parent, and Larivee (1993) concluded that students with high self-efficacy used more metacognitive strategies than students with low self-efficacy. Pajares (2002) points out that regardless of prior achievement, higher selfefficacy is related to greater use of cognitive and metacognitive strategies.

\subsection{Strategies-based instruction}

In the 1990s, there was a shift from simply describing and classifying learning strategies to experimenting with different kinds of interventions in the classroom. The interest was now on whether learners could enhance their language learning by either using new strategies or by using familiar ones more effectively (Cohen \& Weaver 2005). This led to research on strategies-based instruction in second and foreign language contexts which strongly argues for explicit strategy instruction (Graham \& Harris, 2000; National Reading 
Panel, 2000; Pressley, 2000). The rationale behind the strategies-based instruction is that students should be given the opportunity to understand not only what they can learn in the language classroom, but also how they can learn the language they are studying. The model of strategy instruction, used in this study is the Cognitive Academic Language Learning Approach (CALLA) proposed by Chamot and O'Malley (1994).

Until recently, there has been very little empirical research into exploring the possible effect of explicit metacognitive instruction of reading strategies on both leaners' self-efficacy and development of reading comprehension within Iranian context. The present study, then, addressed the following two research questions:

Is there any significant difference between students' reading achievement in the experimental group who have been given the instruction on metacognitive strategies and the control group who have not been given the instruction?

Is there any significant difference between students' self-efficacy in the experimental group who have been given the instruction on metacognitive strategies and the control group who have not been given the instruction?

\section{METHODOLOGY}

\subsection{Participants}

The sample consisted of 100 English majors ( 80 males and 20 females) who were selected through cluster random sampling from among 500 undergraduate EFL majors studying at different universities in Khuzestan, Iran. They ranged in age from 19 to 28 and had already studied English for 6 years at school. The participants were randomly assigned to either experimental $(\mathrm{N}=50)$ or control $(\mathrm{N}=50)$ group.

\subsection{Instruments}

Five main instruments were used in the study: the Survey of Reading Strategies (SORS), Motivated Strategies for Learning Questionnaire (MSLQ), semi-structured interviews, a background questionnaire, and a reading comprehension test.

\subsubsection{The Survey of Reading Strategies (SORS)}

To measure the metacognitive awareness of reading strategies in the experimental and control groups before and after the intervention, this study employed the Survey of Reading Strategies, or SORS (Mokhtari \& Sheorey, 2002; Mokhtari, Sheorey, \& Reichard, 2008). In this instrument each item is accompanied with a 5-point Likert-type scale, 1 (never or almost never do this), 2 (only occasionally do this), 3 (sometimes do this), 4 (usually do this), 5 (always or almost always do this). The higher the number that respondents indicate applies to them, the more frequent the use of the particular strategy is reflected. Mokhtari and Sheorey (2002) provided a key to interpreting the mean for each item and overall item ratings of the SORS. They considered a mean $\leq 2.4$ as low usage, 2.5-3.4 as medium usage, and $\geq 3.5$ as high usage. 
To check the reliability of the instrument for Iranian learners, the SORS was piloted by 60 undergraduate EFL majors $(20=$ male, $40=$ female $)$ who were selected through cluster random sampling from EFL majors studying at different universities in Isfahan. The obtained Alpha Coefficient for the 30 -item SORS was 0.80 , indicating a highly reliable index for the questionnaire. Likewise, the reliability of the SORS for the main study was 0.84 , using Cronbach's Alpha.

The validity of the instrument was also checked by evaluation done by some experts in the field of applied linguistics.

\subsubsection{Motivated Strategies for Learning Questionnaire (MSLQ)}

To assess students' self-efficacy beliefs, the self-efficacy subscale of the Motivated Strategies for Learning Questionnaire (MSLQ) (Printrich, Smith, Garcia, \& McKeachie, 1991) was used. The MSLQ is based on a social-cognitive view of motivation and self-regulated learning (Pintrich, 2003). The MSLQ consists of 15 sub-scales, six within the motivation section and nine within the learning strategies section. Eight items (\#5, \#6, \#12, \#15, \#20, $\# 21, \# 29, \# 31)$ in this scale measure students' self-efficacy for learning and performance. Students rate themselves on a 5-point Likert-type scale, from 1 (not at all true of me) to 5 (very true of me). Scores for the scale are computed by taking the mean of the items that make up the scale. The motive for selection of this instrument was its high index of reliability r=0.93 (Pintrich, Smith, Garcia, \& McKeachie, 1991). Likewise, the reliability of the MSLQ for the present study was 0.85, using Cronbach's Alpha.

\subsubsection{Semi-structured interviews}

In order to increase the reliability of the results of the study and permit a degree of triangulation in the study, some students were chosen randomly from each proficiency group and interviewed by the researcher. The students were asked questions about whether they were familiar with the strategies before the instruction, whether researchers' modeling of the strategies helped them follow the strategies more easily, which strategies they found most useful, and how they felt about the usefulness of the strategy instruction program and its effect on their reading comprehension ability. The researcher also collected retrospective accounts from the experimental teacher as to the structure and content of the treatment class.

\subsubsection{Background questionnaire}

Also, a background questionnaire was used to determine how similar the experimental and control groups were in the following areas: participants' nationality, age, starting age of learning, previous language study, reasons for studying the target language, contact with native speakers (how, where, and why they had had contact), and visits to the target culture (for work, vacation, etc.). T-tests indicated that the two groups did not differ significantly on any of the background characteristics.

\subsubsection{Reading comprehension test}

A reading comprehension test was designed and piloted. The test comprised 50 multiplechoice items with five authentic passages, ranging from 120 to 150 words in length and the 
average readability index 7, using Fog Index. To compute the internal consistency and reliability of the instrument, it was given to 40 undergraduate EFL majors ( $30=$ male, $10=$ female) who were selected through cluster random sampling so as to represent the entire sample of subjects chosen for the main study. The reliability of the test through the KR-21 indicator of reliability was calculated as 0.81 , indicating that the test enjoyed a reliable measure of reading ability. Likewise, the reliability of the test computed for the main study was 0.88 , using KR-21. The validity of the instrument was also checked by evaluation done by some scholars in the field.

To measure the reading ability of the participants, all subjects from the experimental and control groups were asked to complete the same test on a pre-posttest basis to determine whether there were gains in reading ability over the twelve-week term. The reading test was expected to elicit a range of metacognitive reading strategies.

\subsection{Procedure}

The study consisted of three main phases: (1) pretesting (2) strategy instruction and (3) posttesting. Before the strategy instruction, both groups of students were given a test of reading as a pretest in order to assess their current reading comprehension ability. After administering the test of reading, the SORS was given to students in order to assess their current awareness of the metacognitive strategies in reading comprehension. Then, the MSLQ was given to students in order to assess their self-efficacy beliefs in reading comprehension. Before the SORS and MSLQ were administered, the participants were informed about the purpose of them and that there were no right or wrong answers to it. They were also informed that their responses would be confidential and would not affect their course grades.

At the second stage, the participants attended English classes about 60 minutes per week in a twelve-week semester (Spring 2014). During the treatment sessions, the students in the experimental group received instruction in a strategies-based format. More specifica1ly, the strategy instruction phase followed the CALLA Model (adopted from Chamot and O'Malley (1994):

- Stage 1: Preparation. The main purpose of this initial phase for the teacher was to help students identify the strategies they are already using and develop their metacognitive perception of the relationship between their own mental processes and effective learning. In this stage, the teacher talked about the importance of metacognitive reading strategies and a handout including different metacognitive strategies was distributed to the students.

- Stage 2: Presentation. This phase focused on explaining and modeling the learning strategies. The teacher explained the characteristics, usefulness, and applications of the strategy explicitly and through examples and illustrated his own strategy use through a reading task. Learners were explicitly taught about how the strategy is used, why it is important and when and how it applies to the specific task at hand.

- Stage 3: Practice. In the third stage of strategy instruction, learners were given the opportunity of practicing a specific strategy or a set of strategies with an authentic reading task. One of the key characteristics of this phase was to integrate strategy instruction into the regular class work so as the students can make a solid connection between the new strategy and real-life tasks and activities that they must accomplish. 
- Stage 4: Self-evaluation. In this phase, the students were given opportunities to reflect on and evaluate their success or failure in using reading strategies, thus enhancing their metacognitive awareness of their own learning processes. Activities such as debriefing discussions, learning logs, informal self-checklists and open-ended questionnaires were used to develop students' self-evaluation insights.

- Stage 5: Expansion. In this final stage of strategy instruction, students were encouraged to transfer the strategies that they found most effective to new contexts and to develop their own individual combinations and interpretations of metacognitive learning strategies.

During the thirteen-session treatment, the control group received no strategy instruction but underwent a traditional-based instruction on reading. After the instruction period, the same reading comprehension pretest was given as a posttest to both groups. Finally, to compare the perception of the metacognitive reading strategies and self-efficacy beliefs of the experimental group with those of the control group before and after the intervention, the same SORS and MSLQ were given to the experimental group after the instruction.

\subsection{Data analysis}

The Statistical Package for the Social Sciences (SPSS) was employed for the statistical analysis of the data and the significance level of $p<.05$ was set. The analysis included the use of descriptive statistics and inferential tests such as independent t-tests and one-way analysis of covariance (ANCOVA). For scoring the self-efficacy subscale of the Motivated Strategies for Learning Questionnaire (MSLQ) a 5-point Likert scale was used, ranging from 1 (not at all true of me) to 5 (very true of me). Scores for the scale, then, were calculated by summing the items and taking an average for each student. The same procedure was also adopted for the subscales of the Survey of Reading Strategies (SORS).

\section{Results AND DisCuSSION}

4.1. Is there any significant difference between students' reading achievement in the experimental group who have been given the instruction on metacognitive strategies and the control group who have not been given the instruction?

Prior to the treatment and in order to make sure that no significant difference in terms of reading comprehension ability existed between the experimental and control groups, the reading comprehension pretest was administered to both groups. An independent samples ttest was then run to see if the two groups performed significantly differently on the reading comprehension pretest or not. The results obtained from this statistical analysis revealed that the two groups did not differ significantly in their performance on the reading comprehension pretest $(\mathrm{t}=.150, \mathrm{p}=.881)$.

After implementing the thirteen-session training program, all the participants in the two groups were given the reading comprehension posttest, the same test which had been administered as the pretest before starting the training. For the sake of enhancing the reliability of the results of the study and permitting a degree of triangulation, some students were chosen randomly from each proficiency group and interviewed by the researchers on the strategies 
they used, and the strategies they thought most useful and their perception of the usefulness of the strategy training program. Descriptive statistics of the reading comprehension pretest and posttest are summarized in Table 1.

Table 1. Descriptive statistics for the reading comprehension posttest

\begin{tabular}{|l|l|l|l|c|}
\hline \multicolumn{2}{|c|}{ Groups } & N & Mean & Std. Deviation \\
\hline \multirow{3}{*}{ Pretest } & Experimental Group & 50 & 18.28 & 6.28 \\
\cline { 2 - 5 } & Control Group & 50 & 18.08 & 7.06 \\
\hline Posttest & Experimental Group & 50 & 31.96 & 10.65 \\
\hline & Control Group & 50 & 18.92 & 6.06 \\
\hline
\end{tabular}

As Table 1 shows, students in the experimental group obtained much higher mean posttest scores on the reading comprehension test $(\mathrm{M}=31.96, \mathrm{SD}=10.56)$ than the control group $(\mathrm{M}=18.92, \mathrm{SD}=6.06)$. There were higher posttest scores on reading comprehension than pretests in both groups.

In order to see whether the treatment given to the experimental group had statistically caused any significant change in this group and to see if the performance of the students in this group was significantly different from that of the control group, a univariate analysis of covariance (ANCOVA) was conducted, while controlling for pre-intervention scores. Preliminary checks were conducted to ensure that there was no violation of the assumptions of normality, linearity, homogeneity of variances, homogeneity of regression slopes, and reliable measurement of the covariate. As shown in Table 2, the F value for the group is 159.955 which is significant at $\mathrm{p}=.00$, suggesting that reading strategy instruction had a positive effect on the reading comprehension performance of the students in the experimental group on the posttest in contrast to the students in the control group.

Table 2. Results of ANCOVA on post reading scores using pretest as a covariate

\begin{tabular}{|l|c|c|c|c|c|c|}
\hline Source & $\begin{array}{c}\text { Type III Sum } \\
\text { of Squares }\end{array}$ & df & Mean Square & F & Sig. & $\begin{array}{c}\text { Partial Eta } \\
\text { Squared }\end{array}$ \\
\hline $\begin{array}{l}\text { Corrected } \\
\text { Model }\end{array}$ & $9117.992^{\mathrm{a}}$ & 2 & 4558.996 & 177.269 & .000 & .785 \\
\hline Intercept & 459.977 & 1 & 459.977 & 17.885 & .000 & .156 \\
\hline Pretest & 4866.952 & 1 & 4866.952 & 189.243 & .000 & .661 \\
\hline Groups & 4113.719 & 1 & 4113.719 & 159.955 & .000 & .623 \\
\hline Error & 2494.648 & 97 & 25.718 & & & \\
\hline Total & 76332.000 & 100 & & & & \\
\hline Corrected Total & 11612.640 & 99 & & & & \\
\hline
\end{tabular}

a. R Squared=.785 (Adjusted R Squared $=.781$ ) 
The results revealed that the experimental group outperformed the control groups on the reading comprehension test. Moreover, the results obtained from the analysis of the interviews are consistent with those obtained from the statistical analyses. Therefore, the explicit metacognitive strategy training seems to have contributed to the students' ability to apply reading strategies to comprehend the passages. It is likely that the guidance and help the experimental group received contributed to better comprehension. The findings of this study are consistent with those found by recent studies such as Jafari \& Shokrpour, 2012; Karbalaei, 2010; Shokrpour \& Fotovatian, 2009; Takallou, 2011; Zare, 2013; Zare-ee, 2007.

4.2. Is there any significant difference between students' self-efficacy in the experimental group who have been given the instruction on metacognitive strategies and the control group who have not been given the instruction?

The analysis of students' posttest scores of self-efficacy revealed that students in the experimental group obtained higher mean posttest scores on self-efficacy $(\mathrm{M}=3.14, \mathrm{SD}=0.42)$ than the control group $(\mathrm{M}=2.48, \mathrm{SD}=0.54)$. There were higher posttest scores on self-efficacy than on the pretests in both groups. Means and standard deviations for pretest and posttest scores of the two groups are represented in Table 3.

Table 3. Means and standard deviations for pretest and posttest scores on the self-efficacy

\begin{tabular}{|c|l|c|c|c|}
\hline \multicolumn{2}{|c|}{ Groups } & N & Mean & Std. Deviation \\
\hline \multirow{2}{*}{ Pretest } & Experimental Group & 50 & 2.27 & 0.39 \\
\cline { 2 - 5 } & Control Group & 50 & 2.13 & 0.49 \\
\hline Posttest & Experimental Group & 50 & 3.14 & 0.42 \\
\hline & Control Group & 50 & 2.48 & 0.54 \\
\hline
\end{tabular}

To investigate the effect of the explicit metacognitive strategy instruction on the students' self-efficacy while controlling the effect of pretests, again ANCOVA was applied. The results are displayed in Table 4.

Table 4. Results of ANCOVA on post self-efficacy scores using pretest as a covariate

\begin{tabular}{|l|c|c|c|c|c|c|}
\hline Source & $\begin{array}{c}\text { Type III Sum } \\
\text { of Squares }\end{array}$ & df & Mean Square & F & Sig. & $\begin{array}{c}\text { Partial Eta } \\
\text { Squared }\end{array}$ \\
\hline Corrected Model & $11.354^{\mathrm{a}}$ & 2 & 5.677 & 24.223 & .000 & .333 \\
\hline Intercept & 25.255 & 1 & 25.255 & 107.765 & .000 & .526 \\
\hline Pretest & .278 & 1 & .278 & 1.186 & .279 & .012 \\
\hline Groups & 10.277 & 1 & 10.277 & 43.853 & .000 & .311 \\
\hline Error & 22.732 & 97 & .234 & & & \\
\hline Total & 826.846 & 100 & & & & \\
\hline Corrected Total & 34.086 & 99 & & & & \\
\hline
\end{tabular}

a. R Squared=.333 (Adjusted R Squared=.319) 
As Table 4 shows, a statistically significant effect was found for self-efficacy strategy $(\mathrm{F}=43.853, \mathrm{p}=000$, eta squared $=.311)$. This suggests that the students' self-efficacy improved significantly as a consequence of the strategy instruction. Much research shows that teaching students to use learning strategies enhances achievement outcomes, motivation, and selfevaluations of capabilities (Pressley, Woloshyn, Lysynchuk, Martin, Wood, \& Willoughby, 1990; Schunk \& Zimmerman, 1998).

In a meta-analysis of self-efficacy research published between 1977 and 1988, Multon, Brown, and Lent (1991) found a positive relationship between efficacy beliefs and academic achievement in over a decade of published research. The analyses revealed that self-efficacy accounted for approximately $14 \%$ of the variance in academic performance. Graham and Weiner's (1996) review of motivational research revealed similar results with their finding that self-efficacy possessed a stronger relationship to performance in other academic disciplines over and above other motivational constructs.

Students' sense of efficacy affects their academic performance in various ways. Students with a strong sense of academic self-efficacy have been proven to willingly undertake challenging tasks (Bandura \& Schunk, 1981), expend greater effort (Salomon, 1984), show increased persistence in the presence of obstacles (Bandura \& Schunk, 1981; Schunk, 1982a), show lower anxiety levels (Meece, Wigfield, \& Eccles, 1990; Pintrich \& DeGroot, 1990), demonstrate flexibility in the use of learning strategies (Bouffard-Bouchard, 1990; Pintrich \& DeGroot, 1990), and self-regulate better than other students (Zimmerman, Bandura, \& Martinez-Pons, 1992; Zimmerman \& Martinez-Pons, 1990). Students with high self-efficacy also often display accurate self-evaluation of their academic performance and greater intrinsic interest in scholastic matters, and they attain higher intellectual achievement (BouffardBouchard, 1990). Students with low self-efficacy, conversely, may choose to complete only uncomplicated academic tasks to which they apply minimal effort and limited persistence or they may choose to entirely avoid the completion of an academic assignment.

Teachers can also incorporate the sources of efficacy information into the classroom by employing effective strategies such as using peers models (Alderman, 2004; Maag, 1999; Pintrich \& Schunk, 2002; Schunk, 2001), capitalizing on student choice and interest (Pintrich \& Schunk, 2002; Linnenbrink \& Pintrich, 2003), providing frequent focused, task-specific feedback (Schunk \& Zimmerman, 1997; Heward, 2000; Salend (2001), sequencing techniques from easier to more difficult (Brown, 2001) and having students experience learning progress and success.

\section{Conclusion AND IMPlications}

The findings showed that explicit metacognitive strategy instruction, if incorporated into everyday foreign language classroom activities and tasks, can positively and significantly enhance reading achievement and self-efficacy. In practice, this study supported the idea that language classrooms should have a dual focus not only on teaching language content, but also on developing learning processes (Ellis \& Sinclair, 1989; Willing, 1990; Nunan, 1995a, 1995b).

The findings of the present study have implications for learners, teachers, and materials developers in the field of teaching English as a foreign language. University EFL learners 
need to recognize more fully that developing and applying appropriate reading strategies, on the one hand, and developing and employing strategies to build self-efficacy, on the other hand, seem to improve their reading ability in their content subjects and also their academic performance. Furthermore, use of appropriate learning strategies in general and reading strategies in particular can enable students not only to take responsibility for their own learning by enhancing their autonomy, independence and self-direction (Dickinson, 1987) but also to bolster their self-efficacy. These factors are important because learners need to keep on reading when they are no longer in a formal classroom setting (Oxford \& Crookall, 1989).

Therefore, teachers should help them to know not only what strategies to use but also when and how to employ them. In other words, they can assist their students to learn quicker, easier, and more effective by weaving reading strategy training into their regular classrooms activates and tasks. They should explain the characteristics, usefulness, and applications of the strategy explicitly and through several examples and illustrate his/her own strategy use through a reading task. Learners should be explicitly taught about how the strategy is used, why it is important and when and how it applies to the specific task at hand. In essence, the preparation and planning, the selection of appropriate reading strategies, the rationale behind strategy use, monitoring of strategy selection and use, and evaluation of usefulness of metacognitive strategies for reading comprehension should be all elaborated on and exemplified. Moreover, language teachers should provide students with multiple and repeated opportunities to practice the new strategies on a variety of learning tasks and activities so that eventually the strategy itself becomes part of students' procedural knowledge. It is also beneficial that the teacher periodically checks what students have understood and provides them with constructive feedback in order to help them expand their strategy use beyond the language classroom.

Teachers can also help students identify their current metacognitive awareness of reading strategies and their self-efficacy by means of a variety of data collection methods and consciousness-raising techniques such as questionnaires, informal self-checklists, one-on-one and group interviews, diaries, verbal reports, strategy workshops, and other means. Such an approach is likely to help learners to be metacognitively aware as well as to become effective users of the language and eventually to become strategic language learners (Alhaqbani \& Riazi, 2012). Additionally, for the instruction to be more fruitful, teachers should be trained in strategy instruction and assessment.

Materials developers should also play a key role in designing and incorporating tasks and exercises into the reading materials that elicit a wide variety of reading strategies and by providing multiple practice opportunities so that students can employ strategies autonomously. It also seems imperative to take into account EFL readers' real preferences and differences as individuals in designing and developing reading materials that might both influence their choice and use of metacognitive strategies and subsequently enhance their sense of self-efficacy.

\section{Acknowledgments}

We would like to sincerely thank the anonymous reviewers and editors for their valuable comments and suggestions. 


\section{REFERENCES}

Alderman, M. K. (2004). Motivation for achievement: Possibilities for teaching and learning (2nd ed.). (Mahwah, NJ, Lawrence Erlbaum).

Alexander, P. A., \& Jetton, T. L. (2000). "Learning from text: A multidimensional and developmental perspective", in Handbook of reading research, 3: 285-310.

Alhaqbani, A., \& Riazi, M. (2012). "Metacognitive awareness of reading strategy use in Arabic as a second language", in Reading in a Foreign Language, 24, 2: 231-255.

Anderson, N. J. (2002). "Using telescopes, microscopes, and kaleidoscopes to put metacognition into perspective", in TESOL Matters, 12, 4: 1-4.

Baker, L., \& Brown, A. L. (1984). "Cognitive monitoring in reading”, in Understanding reading comprehension, 21-44.

Bandura, A. (1986). Social foundations of thought and action: A social-cognitive view. Englewood Cliffs, NJ: Prentice-Hall.

Bandura, A. (1993). "Perceived self-efficacy in cognitive development and functioning", in Educational Psychology, 28: 117-148.

Bandura, A., \& Schunk, D. H. (1981). "Cultivating competence, self-efficacy, and intrinsic interest through proximal self-motivation", in Journal of Personality and Social Psychology, 41: 586-598.

Barkley, J. M. (2006). "Reading Education: Is Self-Efficacy Important?”, in Reading Improvement, 43, 4: 194-210.

Bouffard-Bouchard, T. (1990). "Influence of self-efficacy on performance in a cognitive task", in The Journal of Social Psychology, 130, 3: 353-363.

Bouffard-Bouchard, T., Parent, S., \& Lavirée, S. (1993). "Self-regulation on a concept-formation task among average and gifted students", in Journal of Experimental Child Psychology, 56, 1: 115-134.

Carrell, P. L., Gajdusek, L., \& Wise, T. (1998). "Metacognition and EFL/ESL reading”, in Instructional Science, 26, 1-2: 97-112.

Chamot, A. U. \& Rubin, J. (1994). "Comments on Janie Rees-Miller's A critical appraisal of learner training: Theoretical bases and teaching implications", in TESOL Quarterly, 28, 4: 771-781.

Chamot, A. U., \& Kupper, L. (1989). “Learning strategies in foreign language instruction”, in Foreign Language Annals, 22, 1: 13-22.

Chamot, A. U., \& O'Malley, J.M. (1994). The CALLA handbook: Implementing the cognitive academic language learning approach. White Plains, NY: Addison Wesley Longman.

Chamot, A. U., Barnhardt, S., El-Dinary, P. B., \& Robbins, J. (1999). The learning strategies handbook. White Plains, NY: Addison Wesley Longman.

Chemers, M. M., Hu, L. T., \& Garcia, B. F. (2001). "Academic self-efficacy and first year college student performance and adjustment", in Journal of Educational Psychology, 93, 1: 55.

Chou, C. (2007). A study on the relationships among English self-efficacy, English learning anxiety, English learning strategies and English learning achievement of senior high school students. Unpublished doctoral dissertation, National Taiwan Normal University, Taipei, Taiwan.

Cohen, A. D., \& Weaver, S. J. (2005). Styles and strategies-based instruction: A teachers' guide. Minneapolis, MN: Center for Advanced Research on Language Acquisition, University of Minnesota.

Coutinho, S. A., \& Neuman, G. (2008). “A model of metacognition, achievement goal orientation, learning style and self-efficacy”, in Learning Environments Research, 11, 2: 131-151. 
Dickinson, L. (1987). Self-instruction in language learning. Cambridge: Cambridge University Press. Ellis, G., \& Sinclair, B. (eds.). (1989). Learning to learn English learner's book: A course in learner training (Vol. 1). Cambridge University Press.

Flaveel, J. H. (1976). "Metacognitive aspects of problem solving", in L. B. Resnick (ed.), The nature of intelligence. Hillsdale, NJ: Erlbaum.

Flavell, J. H. (1979). "Metacognition and cognitive monitoring: A new area of cognitive-developmental inquiry", in American Psychologist, 34: 906-911.

Flavell, J. H. (1987). "Speculations about the nature and development of metacognition", in F. E. Weinert \& R. H. Kluwe (eds.), Metacognition, motivation and understanding. Hillsdale, NJ: Erlbaum.

Flavel 1, J. H. (1992). "Metacognition and cognitive monitoring: A new area of cognitive-developmental inquiry", in T. O. Nelson (ed.), Metacognition: Core readings. Boston, MA: Allyn and Bacon.

Gahungu, N.O. (2007). The relationships among strategy use, self-efficacy, and language ability in foreign language learners. Unpublished PhD dissertation, Northern Arizona University.

Graham, S., \& Weiner, B. (1996). "Theories and principles of motivation", in D. C. Berliner \& R. C. Calfee (Eds.), Handbook of educational psychology. New York: Simon \& Schuster Macmillan, 63-84.

Hacker, D. H. (1998). "Definitions and empirical foundations", in D. H. Hacker, J. Dunlosky \& A. C. Graesser (eds.), Metacognition in educational theory and practice. Mahwah, NJ: Erlbaum.

Jacobs, J. E., \& Paris, S. G. (1987). "Children's metacognition about reading: Issues in definition, measurement, and instruction", in Educational Psychologist, 22: 255-278.

Jafari, S. M., \& Shokrpour, N. (2012). "The reading strategies used by Iranian ESP students to comprehend authentic expository texts in English", in International Journal of Applied Linguistics \& English Literature, 1(4).

Kanfer, R., \& Ackerman, P. L. (1989). "Motivation and cognitive abilities: An integrative/aptitudetreatment interaction approach to skill acquisition", in Journal of Applied Psychology, 74, 4: 657 .

Karbalaei, A. (2010). "A comparison of the metacognitive reading strategies used by EFL and ESL readers", in The Reading Matrix, 10, 2.

Linnenbrink, E. A \& Pintrich, P. (2003). "The role of self-efficacy beliefs in student engagement and learning in the classroom", in Reading and Writing Quarterly, 19: 119-137.

Malcolm, D. (2009). "Reading strategy awareness of Arabic-speaking medical students studying in English", in System, 37: 640-651.

Margolis, H., \& McCabe, P. P. (2006). "Improving self-Efficacy and motivation: What to do, what to say", in Intervention in School and Clinic, 41, 4: 218-227.

Meece, J. L., Wigfield, A., \& Eccles, J. S. (1990). "Predictors of math anxiety and its influence on young adolescents' course enrollment intentions and performance in mathematics", in Journal of Educational Psychology, 82, 1: 60.

Mills, N., Pajares, F., \& Herron, C. (2007). "Self $\square$ efficacy of college intermediate French students: Relation to achievement and motivation", in Language Learning, 57, 3: 417-442.

Mokhtari, K., \& Sheorey, R. (2002). "Measuring ESL students' awareness of reading strategies", in Journal of Developmental Education, 25: 2-11.

Mokhtari, K., Sheorey, R., \& Reichard, C. (2008). "Measuring the reading strategies of first and second language readers", in K. Mokhtari \& R. Sheorey (eds.), Reading strategies of first- and second-language learners: See how they read. Norwood, MA: ChristopherGordon, 43-65. 
Multon, K. D., Brown, S. D., \& Lent, R. W. (1991). "Relation of self-efficacy beliefs to academic outcomes: A meta-analytic investigation", in Journal of Counseling Psychology, 38, 1: 30.

National Reading Panel (2000). Report of the National Reading Panel: Teaching children to read. Retrieved from http://www.nichd.nih.gov/publications/nrp/smallbook.htm.

Nevil, A.M. (2008). The impact of reading self-efficacy and the regulation of cognition on the reading achievement of an intermediate elementary sample. Unpublished PhD dissertation, Indiana University of Pennsylvania.

Nunan, D. (1995a). "Closing the gap between learning and instruction", in TESOL Quarterly, 29, 1: 133-158.

Nunan, D. (1995b). Atlas: Learning-centered communication. Levels 1-4. Boston, MA: Heinle \& Heinle Pub.

Oxford, R., \& Crookall, D. (1989). "Research on language learning strategies: Methods, findings, and instructional issues", in The Modern Language Journal, 73, 4: 404-419.

Pajares, F. (2002). "Overview of social cognitive theory and self-efficacy". Retrieved from http:// www.emory.edu. EDUCATION/mfp/eff.htm.

Paris, S. G., \& Jacobs, J. E. (1984). "The benefits of informed instruction for children's reading awareness and comprehension skills", in Child Development, 55: 2083-2093.

Pintrich, P. R. (2003). "A motivational science perspective on the role of student motivation in learning and teaching contexts", in Journal of Educational Psychology, 95, 4: 667.

Pintrich, P. R., \& De Groot, E. V. (1990). "Motivational and self-regulated learning components of classroom academic performance", in Journal of Educational Psychology, 82, 1: 33.

Pintrich, P. R., \& Schunk, D. (2002). Motivation in education: Theory, research, and applications (2nd ed.). Upper Saddle, NJ: Prentice-Hall, Inc.

Pintrich, P.R, Smith, D.A.F., Garcia, T., \& McKeachie, W.J. (1991). A manual for the use of the motivated strategies for learning questionnaire (MSLQI). Ann Arbor, MI: NCRIPTAL, The University of Michigan.

Pressley, M. (2000). "What should comprehension instruction be the instruction of?", in M. L. Kamil, P. B. Mosenthal, P. D. Pearson, \& R. Barr (eds.), Handbook of reading research. Mahwah, NJ: Lawrence Erlbaum, Vol. III, 545-561

Pressley, M., Woloshyn, V., Lysynchuk, L. M., Martin, V., Wood, E., \& Willoughby, T. (1990). "A primer of research on cognitive strategy instruction: The important issues and how to address them", in Educational Psychology Review, 2: 1-58.

Rings, S., (1994). The role of computer technology in teaching critical reading. Retrieved from: http://www.mcli.dist.maricopa.edu/critr.

Schunk, D, H, (1982a). "Effects of effort attributional feedback on children's perceived self-efficacy and achievement", in Journal of Educational Psychology, 74: 548-556.

Schunk, D. H. (2001). "Social cognitive theory and self-regulated learning", in B. J. Zimmerman \& D. H. Schunk (eds.), Self-regulated learning and academic achievement: Theoretical perspectives (2nd ed., pp. 125-151). Mahwah, NJ: Lawrence Erlbaum Associates, Inc.

Schunk, D. H., \& Zimmerman, B. J. (eds.) (1998). Self-regulated learning: From teaching to self-reflective practice. New York: Guilford Press.

Shokrpour, N. \& Fotovatian, S. (2009). "Effects of consciousness raising of metacognitive strategies on EFL students' reading comprehension", in ITL - International Journal of Applied Linguistics, 157, 75-92.

Takallou, F. (2011). "The effect of metacognitive strategy instruction on EFL Learners' reading comprehension performance and metacognitive awareness", in Asian EFL Journal, 13, 1.

Weinstein, C.E., \& Mayer, R.E. (1986). "The teaching of learning strategies", in M. C. Wittrock (ed.), Handbook of research on teaching. New York: Macmillan, 3rd ed, 315-327. 
Wenden, A. (1987). "Metacognition: An expanded view on the cognitive abilities of L2 learners", in Language Learning, 37, 4: 573-597.

Wenden, A. L. (1998). "Metacognitive knowledge and language learning", in Applied Linguistics, 19, 4: 515-537.

Willing, K. (1990). Teaching how to learn. Sydney, Australia: National Center for English Language Teaching and Research.

Wu, C.P. (2006). The effects of goal orientation, self-efficacy, and cognitive/metacognitive selfregulatory strategy use on EFL college students' course achievement. Unpublished PhD dissertation, University of Southern California.

Zare, P. (2013). "Exploring reading strategy use and reading comprehension success among EFL Learners", in World Applied Sciences Journal, 22, 11.

Zare-ee, A. (2007). "The relationship between cognitive and metacognitive strategy use and EFL reading achievement", in Journal of Applied Psychology, 2: 105-119.

Zhang, L. F. (2010). "Further investigating thinking styles and psychosocial development in the Chinese higher education context", in Learning and Individual Differences, 20, 6: 593-603.

Zhang, L. J. (2001). "Awareness in reading: EFL students' metacognitive knowledge of reading strategies in an acquisition-poor environment", in Language Awareness, 10, 4: 268-288.

Zimmerman, B. J., \& Martinez-Pons, M. (1990). "Student differences in self-regulated learning", in Journal of Educational Psychology, 82: 51-59.

Zimmerman, B. J., Bandura, A., \& Martinez-Pons, M. (1992). "Self-motivation for academic attainment: The role of self-efficacy beliefs and personal goal setting", in American Educational Research Journal, 29: 663-676. 